\title{
PÓS-ESTRUTURALISMO E ANÁLISE ORGANIZACIONAL
}

O pós-estruturalismo representa uma grande contribuição para a teoria organizacional, especialmente no que diz respeito a novas tentativas de compreensão das organizações e da prática da administração. O pensamento de uma grande gama de filósofos fornece a base dessa perspectiva em análise organizacional, destacando-se principalmente Michel Foucault, Jaques Derrida, Jean Baudrillard, Giles
Deleuze e Felix Guattari. O foco é ir além do pensamento estruturalista e dos modelos sistêmicos. Christine McLean, lecture e especialista em análise organizacional pós-estruturalista da Manchester School of Management na UMIST, Inglaterra, e Rafael Alcadipani, mestrando em organizações e recursos humanos na FGV-EAESP, destacaram algumas das inúmeras obras relevantes elaboradas sob essa perspectiva.

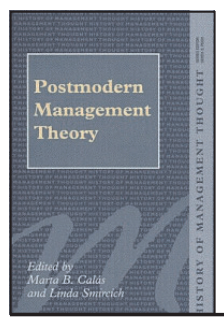

\section{POSTMODERN MANAGEMENT THEORY}

Marta B. Calás e Linda Smircich. London : Sage, 1997. 328 p.

Essa coletânea apresenta um conjunto de autores renomados em análise organizacional que estudaram as organizações pelo prisma pós-estruturalista. Dentre eles, podemos citar Jermier, Cooper, Parker, Burrell, Townley e Boje. Eles oferecem-nos uma discussão interessante e inteligente sobre as organizações. De forma geral, os artigos expõem diferentes abordagens provocativas para estudar e compreender a administração e as organizações.

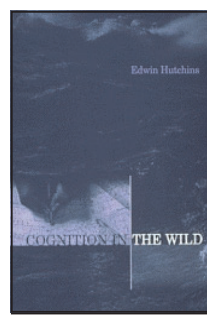

\section{COGNITION IN THE WILD}

Edwin Hutchins. Boston : The MIT Press, 1996. 283 p.

Pode parecer estranho esse livro constar na nossa seleção. Porém, ao tomar contato com ele, você perceberá os insights interessantes fornecidos para a análise das organizações. Essa obra está baseada na noção de distribuição cognitiva e da propagação da informação, não pela mente dos indivíduos, mas, sim, pela representação da organização. Assim, ele fornece uma contribuição importante para nossa compreensão do processo de organização, fazendo-nos repensar como sistemas complexos de pessoas e coisas se relacionam e são constituídos dentro de contextos particulares.

\section{SORTING THINGS OUT}

Geoffrey Bowker e Susan Star. Boston : The MIT Press, 2000. 180 p. Um dos principais aspectos referentes às organizações é o processo de classificação. Processos de classificação são o tema principal desse livro. Vários exemplos ilustram o processo complicado que está no pano de fundo dos sistemas de classificação que passaram a existir na esfera da medicina, doenças, sistemas de saúde e raça. Além disso, ele destaca a importância dos sistemas de classificação em termos de teoria das organizações, já que faz referência particular às conseqüências éticas e sociais relacionadas com a construção e aplicação prática dos sistemas classificatórios.
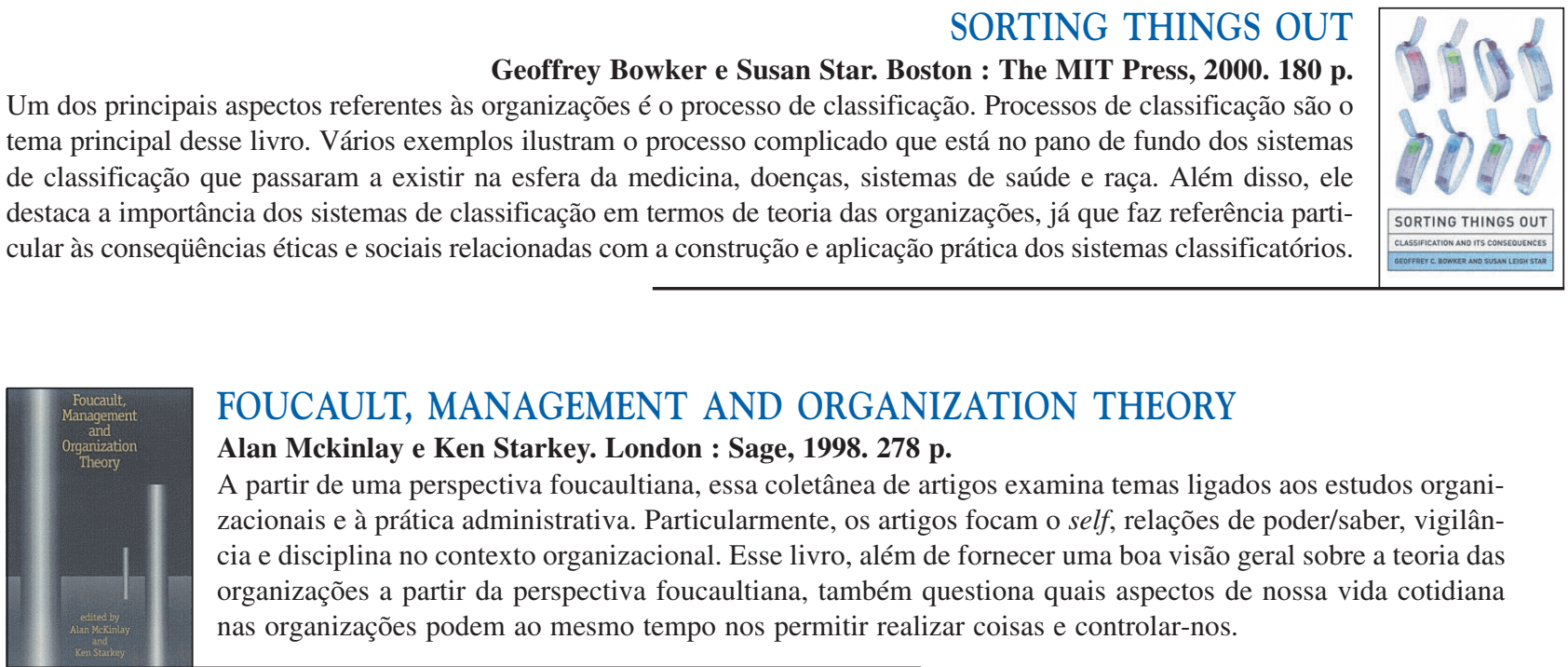

\section{FOUCAULT, MANAGEMENT AND ORGANIZATION THEORY}

Alan Mckinlay e Ken Starkey. London : Sage, 1998. 278 p.

A partir de uma perspectiva foucaultiana, essa coletânea de artigos examina temas ligados aos estudos organizacionais e à prática administrativa. Particularmente, os artigos focam o self, relações de poder/saber, vigilância e disciplina no contexto organizacional. Esse livro, além de fornecer uma boa visão geral sobre a teoria das organizações a partir da perspectiva foucaultiana, também questiona quais aspectos de nossa vida cotidiana nas organizações podem ao mesmo tempo nos permitir realizar coisas e controlar-nos. 